\title{
The Text Analysis of Poesponegoro Manuscript
}

\author{
Asep Abbas Abdullah \\ Universitas Islam Negeri Sunan Ampel \\ Surabaya, Indonesia
}

\author{
Alda Dea Delfina \\ Universitas Islam Negeri Sunan Ampel \\ Surabaya, Indonesia
}

\begin{abstract}
The goals of education is not only to create smart and multitalented generations. Other goals that education must achieve is creating generations who can behave properly everywhere. There are many ways to build good characters on students. One of the way is by knowing and learning about the values of life through local cultures or heritages. In this study, the researcher would like to use Poesponegoro manuscript as the subject of the study. There are three inqueries to be analyzed such as the origin, the inheritance process and the moral values taken from the manuscript. As this research is a philology study, the researcher used several methods to collect and analyze the data such as using interview and documentation. The result showed that the manuscript is still origin and the process of inheritance was through translated written text, genealogists, relics and traditions or customs. Moreover, it showed that there are several moral values that can be learned from Poesponegoro manuscript such as honesty and fairness values, hard working value, religiousness value, devotion and patriotism values.
\end{abstract}

Keywords: Poesponegoro manuscripts, character education, local cultures

\section{INTRODUCTION}

The goals of education is not only to create smart and multitalented generations. Other goals that education must achieve is creating generations who can behave properly everywhere. Building good characters to the students is not a simple thing, there is a long process to do it since good characters are influenced by many factors. However, there are many ways to build good characters on students. One of the way is by knowing and learning about the values of life. The moral values can be learned through the study of local culture. In Indonesia, students are usually taught values that related to Indonesian local cultures. Local culture is the identity of the nation because it is rooted in the culture of the supporting community. Regarding the richness of Indonesian cultures, it is important to preserve and develop the learning of local cultures. Another reason is because not all values coming from other countries are suitable with the way Indonesian people behave and the characteristic of Indonesian people itself.

One of the local culture or heritage that can be used as a tool to build good character is using the inscription. The inscriptions often contain of a lot of stories, symbols, values and messages for the next generations. Therefore, in this study, the researcher would like to use Poesponegoro inscription as the subject of the study. This researchers focus on analyzing the manuscript of Poesponegoro as a tool to learn about the values to build good characters on students. Moreover, this study has a significance to strengthen the awareness and the pride in the local culture is an attitude that needs to be cultivated especially for the students as the future generation.

Therefore, in this study, there are three inqueries to be analyzed. First, the researchers attempt to find out whether Poesponegoro manuscript is original and remained the same during hundred years. Second, the researchers try to investigate how cultural elements of Poesponegoro manuscript are passed down from one generation to others. Third, the researchers try to analize what moral values can be learned from Poesponegoro manuscript to help building character.

According to Clark Wissler, Ralph Linton, and his friends (Brunvand, 1968: 2-3 in Danandjaja, 1997: 171), culture has many elements which was translated into the activities of culture (cultural activities), the complex elements (trait complex), elements (traits), minor elements (items), and folklore (also has elements such as French genre / read syanre). The cultural heritage means a heritage that left by previous generations to the present generation. The cultural heritage of Gresik society (Poesponegoro Inscriptions) are aspects related to social and cultural life of society which are constantly maintained and practiced until now.

Their heritages are aimed to facilitate the communication between the current community to the lives of the previous society. This legacy is also a proof of the existence and role of Gresik on the stage of history. However, through the course of time, what is left by past societies Gresik has experienced the development, modification, and even perversion. The change is understandable because of the legacy has been passed through the passage of time, socio-cultural changes are quite long, with varying intensity, each period has its own characteristics.

There are eighteen values based on Indonesian culture which is stated in curriculum of character education in Indonesia (Permedikbud, 2018). The values include religious, honest, tolerant, discipline, hard working, creative, self reliant, democratic, curious, spirit nationalist, 
nationalism or patriotism, respect, communicative, peaceful, reading literacy, environment care, social care and responsible. Those characters should be known, understood and implemented by students to be not only smart people but also good and wise generations.

\section{METHOD}

This study was a Philology research. Philology is the study of language in oral and written historical sources. It is the intersection of textual criticism, literary criticism, history, and linguistics (Watkins, 1990). Philology is more commonly defined as the study of literary texts as well as oral and written records, the establishment of their authenticity and their original form, and the determination of their meaning (Watkins, 1990). Through this philology study, researchers expected to understand the purpose and meaning of the ancient texts whose language is no longer familiar in everyday lives, in order to learn the values written in the ancient text and perhaps able to use the moral values to educate people.

The subject of this research was the inscription of Asmaratakan or well known as the inscription of Poesponegoro Gresik. This inscription was one of cultural heritages which is left by previous generations to the present generation. The Poesponegoro inscription was located in Gresik regent family grave sites in Gapuro village, Gresik. In this grave site, there were several tombs. However, the main tomb was the tomb of Poesponegoro who was being the second regent of Gresik in 1695 to 1730 . In this grave cluster, there are 8 (eight) cupola made of white stone and 3 (three) cupola made of wood. Poesponegoro cupola is lied in the northest area which was made of black andesite, with a fairly good condition. The tombstones in this cluster looked like Demak and Troloyo tombstones types. The height was 1,75 meter, the widht was 1.10 meter and the thickness: 15 $\mathrm{cm}$. It was approximately made in $1669 \mathrm{AD}$.

There were found several Poesponegoro inscriptions in the grave sites of Gapuro village, Gresik. In this study, the researcher chose one of the inscription and collected the data through the analysis of the text in one of Poesponegoro manuscript written on the inscription. The text was written using Sansekerta words. There were 11 lines of words analyzed in this study. Those words were translated into several language such as Bahasa Indonesia, Javanese Language and English versions, in order to understand the meanings and take the values of the manuscript. Moreover, the researchers did some library research and interviewed with several local people in Gresik to ensure that there were not found any changing of the manuscripts since the inscription was aged hundred years. The library research and interview were also aimed to ensure that there were not found any different interpretations towards the text translation. The researcher also took some photos of the inscription and manuscripts as documents.

\section{FINDINGS AND DISCUSSION}

Based on library research, interview, observation and documentation, the Poesponegoro manuscript was still original. It means that there were unchanged content of the text. It also showed that the meaning or interpretations towards the Poesponegoro manuscript never changes. The purpose, meaning and the interpretation of text remain the same although it is translated into any different languages such as Jawa, Bahasa Indonesia and English.

To answer the second first research question, based on the data collections, there were found several ways to pass down the cultural elements from Poesponegoro manuscript from one Gresik generation to others, such as through the copy of the translated text, through genealogists, through relics, and through traditions and cutoms.

a. First, heritage in the form of writing or text became the primary tool to proceed a cultural inheritance, especially when it was authentic writing gotten from the previous era. Since the ancient times, in Java, there were various types of writing or language used in manuscripts such as Pallawa, Sanskrit, Javanese or Arabic script. However, Gresik people used the copy of the translated text to pass down the cultural elements. They copied, translated the texts which were written in Java pegon, Sanskrit or even Arabic language into more familiar language such as Bahasa Indonesia. The translation of the text was needed due to various limitations, and in accordance with the socio-cultural context of the time.

b. Second, genealogists were helpful in passing down the cultural elements. The genealogists were not only having the function of legitimating the cultural elements, they also had contributions to spread the cultural elements to the local people. The genealogists were the people who had desire to carve out a place for one's family in the larger historical picture, a sense of responsibility top reserve the past for future generations.

c. Third, the relics such as the art of building, relief, gravestone tools of life, art tools, and so forth were another way to inherit the cultural elements. The poesponegoro inscriptions and manuscripts were the examples of relics that became tools to pass down the cultural elements. People can take the moral values or find the historical stories behind the relics.

d. Fourth, the cultural elements were inherited through traditions or customs. Tradition usually associated with customs, beliefs, doctrine, which was passed down from ancestors. Tradition was a form of information about the beliefs, testimonies of the past, spoken through word of mouth from generation to generation in the relay or successively.

Regarding the second research question about the moral values of Poesponegoro manuscript, the researcher did textual criticisms toward eleven lines in Poesponegoro manuscript. Based on the text criticism, it was found that the 
content of Poesponegoro did not experience any changes although it had lied for hundred years. Therefore, the meaning and the value of the text remained the same from generation to generation.

In character education, there are 18 values that relate to Indonesian local culture. According to the analysis of Poesponegoro manuscript, the researcher could highlight several moral values, such as: honesty and fairness, hard working, religiousness, devotion and patriotism values

a. Showing honesty and fairness values

- The first line, "Fair regent governs wisely".

- Sixth row, "Someone who ruled Gresik in the past (Poesponegoro)".

b. Showing hard working value

- The second line, "People live in a prosperity and in a happiness"

- The third line, "The water that flows giving life to us and flows throughout the year"

c.Showing religiousness value

- The fourth line, "It is a sign that our land (Gresik) is blessed by the Lord of the Universe (Allah)."

- Ninth line, "In order for us to feel sufficient to worship".

- Tenth line, "To our Lord,"

- Eleventh row, "Allah, the Lord of the nature".

d.Showing devotion

- Seventh lines, "For us (Gresik people) who are docile and obedient".

- Fifth row, "This is the gift of heredity Malik Ibrahim".

e.Showing patriotism value

- Eighth row, "In our paddy fields".

\section{CONCLUSION}

Based on the findings above, it can be concluded that Poesponegoro manuscripts was still original. It was inherited from one generation to another through heritage in the form of writing or text, genealogists, relics such as the art of building, relief, gravestone tools of life, art tools, and so forth, and traditions or customs. Then, there are several moral varul values that can be learned or can be used to build good character such as: honesty and fairness values, hard working value, religiousness value, devotion and patriotism values.

Furthermore, this study gives several implications to the character education, language teaching and cultural studies. First, for character education, the manuscript of poesponegoro can be a tool to build good characters to people. There are more values that can be learned and taught to today's people. Second, in order to know the content of Poesponegoro manuscript, people need to learn various languages. It means that by conducting this study, people will more aware towards the importance of languages learning, not only mono-language but multi-languages. Third, the implication in cultural study is by learning about poesponegoro inscription and manuscript, people will not only learn about Indonesian local culture but also preserve it for the next generations.

\section{REFERENCES}

Aqib, Z. (2010). Pendidikan karakter membangun perilaku positif anak bangsa. Bandung: Yrama Widya.

Danandjaja, James. 1997. Folklor Indonesia: Ilmu Gosip, Dongeng, dan lain-lain. Jakarta: Pustaka Utama Grafiti.

Hutomo, Suripan Sadi. 1999. Filologi Lisan: Telaah Teks Kentrung. Jakarta: CV. Lautan Rezeki.

Van Peursen, C.A. 1976. Strategi Kebudayaan (Terjemahan Dick Hartoko). Jakarta: BPK Gunung Mulia.

Watkins, Calvert. 1990. What is Philology?. Comparative Literature Studies: vol.27(1), pp 21-25. 